\title{
Problem ubóstwa w Unii Europejskiej
}

\section{Wprowadzenie}

U bóstwo kojarzy się zwykle z krajami tzw. „Trzeciego Świata” odległymi terytorialnie od współczesnych ośrodków cywilizacyjnych, do których należy także Europa. Wymownym wskaźnikiem tego zjawiska jest problem głodu i niedożywienia. Statystyki prowadzone przez Food and Agriculture Organization, jedną z agend Organizacji Narodów Zjednoczonych monitorującą poziom globalnego głodu wskazują, że od schyłku lat 90 . ubiegłego stulecia liczba głodujących stale ulega zmniejszeniu, przy czym w ostatnich latach widać wyraźny spadek dynamiki zmian. Na tę sytuację bez wątpienia ogromny wpływ miał kryzys finansowo-gospodarczy z lat 2006-2009, który wywołał lawinowy wzrost cen żywności. Jak podają szacunki na 2012 r. liczba osób cierpiących z powodu głodu i niedożywienia sięgnie $868 \mathrm{mln}$, co stanowi wyraźny spadek w stosunku do ok. $1 \mathrm{mld}$ w latach 1990-1992 ${ }^{1}$. Nie ulega jednak wątpliwości, iż pomimo widocznych efektów, skala zjawiska wskazuje na konieczność podejmowania dalszych działań w kierunku jego redukcji.

Ubóstwo jest problemem niezmiennie aktualnym i dotyczy całego świata. Jest sprawą niebudzącą wątpliwości, iż w głównym stopniu problem ubóstwa i głodu dotyczy ludności krajów najbiedniejszych, jednakże wskutek nieodległego kryzysu, stał się bardziej widoczny także w państwach rozwiniętych. Obecnie niespełna jeden na siedmiu mieszkańców Unii Europejskiej jest zagrożony ryzykiem ubóstwa. Co więcej, w niektórych grupach społecznych, np. wśród osób starszych czy też dzieci, wskaźniki te są jeszcze wyższe ${ }^{2}$.

Przyczyn ubóstwa w regionach rozwiniętych upatruje się w nieprawidłowym funkcjonowaniu systemów redystrybucji zasobów. Prowadzą one do głębokich nierówności społecznych charakteryzujących się dwubiegunowością. Na jednym krańcu znajdują się nieliczni posiadający znaczne zasoby majątkowe, na drugim zaś są zepchnięte na margines życia osoby borykające się z problemem ubóstwa, mimo iż żyją na bogatym obszarze gospodarczym ${ }^{3}$.

\section{Ubóstwo - ustalenia terminologiczne}

W literaturze dotyczącej zagadnień zróżnicowania poziomu życia, a także praktyce Unii Europejskiej funkcjonują różne wskaźniki ubóstwa, co jest bezpośrednio związane z odmiennym sposobem jego definiowania. Jedna z najogólniejszych typologii rozróżnia ubóstwo bezwzględne - skrajne oraz ubóstwo względne - relatywne. O pierwszym z nich mówi się

${ }^{1}$ The State of Food Insecurity in the World. Economic growth is necessary but not sufficient to accelerate reduction of hunger and malnutrition, Food and Agriculture Organization of the United Nations, Rome 2012, s. 8-9.

${ }^{2}$ Poverty and inequality in the EU, European Anti Poverty Network Explainer 1, 2009, s. 2.

${ }^{3}$ Poverty and inequality in the EU, European Anti Poverty Network Explainer 1, 2009, s. 2. 
w sytuacji braku podstawowych środków do przeżycia. Obejmuje ono takie zjawiska jak głód, brak dostępu do czystej wody, odpowiednich warunków mieszkaniowych, odzieży czy leków i wiąże się z permanentną walką o przetrwanie. Ten rodzaj ubóstwa dotyczy przede wszystkim państw rozwijających się, jednakże również w Unii Europejskiej dotyka pewnych grup społecznych tj. bezdomnych czy Romów. Pojęcie ubóstwa relatywnego jest natomiast używane w stosunku do ludzi, których poziom życia i dochodów mocno odbiega od standardów jakie obowiązują w ich kraju czy regionie. Sytuacja ta rzutuje następnie na ograniczone możliwości uczestnictwa tych osób w sferze aktywności ekonomicznej, socjalnej i kulturalnej ${ }^{4}$.

Należy przy tym zaznaczyć, iż wskaźniki tego rodzaju ubóstwa są zrelatywizowane do danego kraju i zależą od standardu życia większości społeczeństwa. Unia Europejska w procesie integracji społecznej odnosi się do pojęcia ubóstwa relatywnego, które rozumiane jest jako poziom dochodów i zasobów, który jest niewystarczający aby zapewnić dopuszczalny w danej społeczności standard życia. Z tak rozumianym ubóstwem skorelowane są złożone problemy takie jak bezrobocie, niskie dochody, złe warunki mieszkaniowe, niewystarczający dostęp do opieki zdrowotnej, kształcenia ustawicznego, kultury, sportu czy też różnych form rekreacji. Ponadto zwraca się uwagę, iż osoby ubogie są często wykluczane z pełnego uczestnictwa w działalności gospodarczej, społecznej czy kulturalnej, a ich dostęp do podstawowych praw może być ograniczony ${ }^{5}$.

Ubóstwo na poziomie Unii Europejskiej mierzone jest m.in. za pomocą miernika zagrożenia ubóstwem i wykluczeniem społecznym. Na wskaźnik ten składa się suma osób:

- zagrożonych ubóstwem,

— żyjących w warunkach poważnej deprywacji materialnej,

— żyjących w gospodarstwie domowym o bardzo małej intensywności pracy ${ }^{6}$.

O zagrożeniu ubóstwem mówi się, gdy osoba dysponuje przychodem na poziomie poniżej progu zagrożenia ubóstwem, za który przyjmuje się 60\% krajowej mediany dochodu do dyspozycji (po transferach socjalnych). Deprywacja materialna obejmuje wskaźniki związane z obciążeniem ekonomicznym i artykułami trwałego użytku. Osoba jest rozpoznawana jako dotknięta deprywacją materialną, jeżeli nie stać ją na co najmniej 4 z 9 następujących:

- opłacenie czynszu lub rachunków za media,

- utrzymanie odpowiedniej temperatury w domu,

- pokrycie niespodziewanych wydatków,

- spożywanie mięsa, ryb lub odpowiednika białka co drugi dzień,

- spędzenie tygodniowych wakacji poza domem,

- samochód,

- pralkę,

\footnotetext{
${ }^{4}$ Komisja Europejska używa definicji, wedle której ludzie żyją w ubóstwie, jeżeli ich dochody i środki są niewystarczające do życia na poziomie uznanym w ich społeczności za akceptowany. Ich ubóstwo może być źródłem kolejnych problemów takich jak: bezrobocie, niskie dochody, ubogie mieszkanie, niewystarczająca opieka medyczna, bariery w dostępie do kształcenia ustawicznego, kultury, sportu i rekreacji. Są oni także często wykluczani z partycypacji w aktywnościach normalnych i dostępnych dla innych, przez co ich fundamentalne prawa mogą być ograniczone. Por. Joint report on social inclusion, Social security and social integration, European Commission, Luxemburg 2004, s. 10. Znaczenie terminu ,ubóstwo relatywne” po raz pierwszy zostało uzgodnione przez Radę Europejską w 1975 r. Por. Combating poverty and social exclusion. A statistical portrait of the European Union 2010, Eurostat, Luxemburg 2010, s. 6; Poverty and inequality in EU, European Anti Poverty Network, 2009, s. 5.

${ }^{5}$ Poverty and inequality in the EU, European Anti Poverty Network Explainer 1, 2009, s. 5.

${ }^{6}$ Na poziomie wskaźnika ogólnego, dana osoba liczona jest tylko raz, mimo że może dotyczyć jej więcej niż jedna forma ubóstwa lub wykluczenia społecznego.
} 
— telewizor kolorowy,

- telefon.

O bardzo niskiej intensywności pracy świadczy natomiast sytuacja, w której osoby w wieku 0-59 lat żyją w gospodarstwach domowych, których dorośli członkowie (18-59 lat) pracują mniej niż $20 \%$ ich potencjalnego czasu pracy w ciagu ostatniego roku ${ }^{7}$.

\section{Demografia jako czynnik ubóstwa}

Z punktu widzenia ubóstwa ludności państw europejskich niezwykle ważny w kwestiach demograficznych jest tzn. wiek społeczeństwa. Od dłuższego już czasu wskazuje się na problem starzejącej się populacji krajów zachodnioeuropejskich. Kwestia ta jest o tyle istotna, iż największy odsetek ubogich notuje się wśród osób starszych, ich liczba zaś ustawicznie rośnie.

Wykres 1. Zmiany w populacji osób w wieku 60 lat i więcej w latach 1950-2050

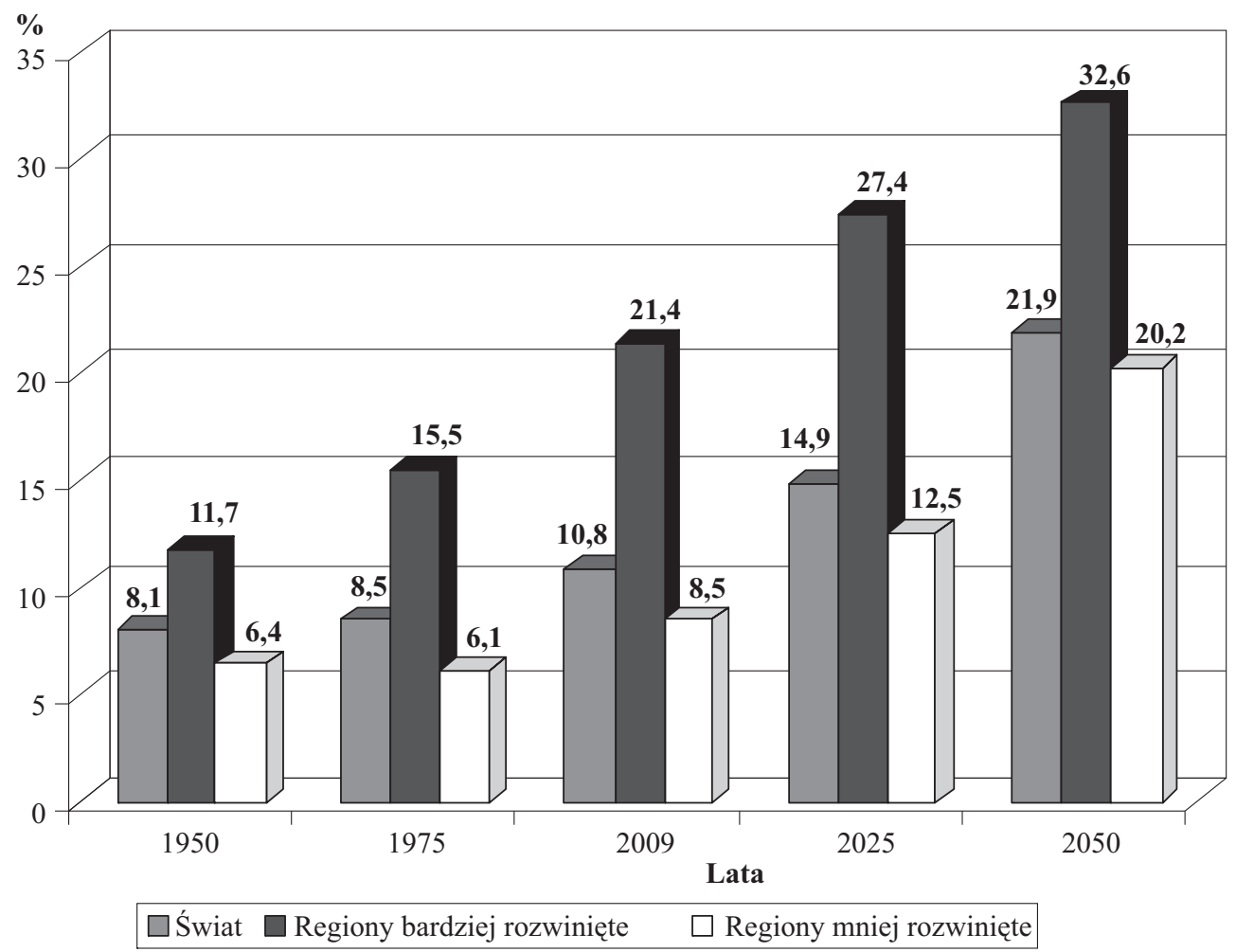

Regiony bardziej rozwinięte - zaliczono do nich wszystkie regiony Europy, Ameryki Północnej, Australię, Nową Zelandię i Japonię.

Regiony mniej rozwinięte - obejmują wszystkie regiony Afryki, Azji (wyłączając Japonię), Ameryki Łacińskiej i Karaibów oraz Melanezji, Polinezji i Mikronezji.

Źródło: Population ageing and development 2009, United Nations, New York 2010.

\footnotetext{
${ }^{7} \mathrm{http}: / /$ epp.eurostat.ec.europa.eu/tgm/table.do?tab=table\&init=1\&language=en\&pcode=t2020_50\&plugin=1.
} 
W latach 1950-2009 udział osób powyżej 60 r.ż. w światowej populacji wzrósł o ponad 2 pkt procentowe. Podobny przyrost odnotowano w regionach mniej rozwiniętych. W tym samym czasie natomiast regiony bardziej rozwinięte odnotowały w tym zakresie wzrost niespełna 10-procentowy. Szacunki na następne lata wskazują, iż w tych regionach takie tempo ma się utrzymać. Poważne zmiany mają nastąpić natomiast w obszarze tego wskaźnika w odniesieniu do populacji świata oraz regionów mniej rozwiniętych. W obu przypadkach liczba osób powyżej 60 r.ż. zwiększy się o ponad 11 pkt procentowych.

Niezwykle niepokojące w tym kontekście są dane oraz szacunki ONZ, wedle których do roku 2050 na świecie liczba osób powyżej 60 roku życia zwiększy się aż o 63,3\%. Na obszarach bardziej rozwiniętych, do których zalicza się Europę, wzrost ten wyniesie 36,6\%.

Udzial osób starszych w populacji

Tabela 1

\begin{tabular}{|c|c|c|c|c|c|c|c|c|}
\hline \multirow{3}{*}{ Kraj/region } & \multicolumn{6}{|c|}{ Osoby w wieku 60 lat lub więcej } & \multirow{2}{*}{\multicolumn{2}{|c|}{$\begin{array}{c}\text { Wskaźnik } \\
\text { wsparcia osób } \\
\text { powyżej } 65 \text { roku } \\
\text { życia }\end{array}$}} \\
\hline & \multicolumn{2}{|c|}{ tys. } & \multicolumn{2}{|c|}{$\begin{array}{c}\text { \% calej } \\
\text { populacji }\end{array}$} & \multicolumn{2}{|c|}{$\begin{array}{l}\text { udział osób powyżej } 80 \text { roku } \\
\text { życia w populacji osób powy- } \\
\text { żej } 60 \text { r.ż. }\end{array}$} & & \\
\hline & 2009 & 2050 & 2009 & 2050 & 2009 & 2050 & 2009 & 2050 \\
\hline 1 & 2 & 3 & 4 & 5 & 6 & 7 & 8 & 9 \\
\hline Świat & 737275 & 2008244 & 11 & 22 & 14 & 20 & 9 & 4 \\
\hline $\mathrm{RBR}^{\mathrm{a}}$ & 263905 & 416055 & 21 & 33 & 20 & 29 & 4 & 2 \\
\hline $\mathrm{RMR}^{\mathrm{b}}$ & 473370 & 1592188 & 8 & 20 & 11 & 10 & 11 & 4 \\
\hline $\mathrm{RNR}^{\mathrm{c}}$ & 42922 & 185129 & 5 & 11 & 8 & 10 & 17 & 9 \\
\hline Europa & 158503 & 236426 & 22 & 34 & 19 & 28 & 4 & 2 \\
\hline Europa Wschodnia & 55486 & 80624 & 19 & 34 & 16 & 20 & 5 & 2 \\
\hline Bułgaria & 1824 & 2059 & 24 & 38 & 15 & 22 & 5 & 2 \\
\hline Czechy & 2255 & 3547 & 22 & 34 & 16 & 23 & 5 & 2 \\
\hline Polska & 7174 & 12175 & 19 & 38 & 17 & 22 & 5 & 2 \\
\hline Rumunia & 4256 & 6391 & 20 & 37 & 15 & 20 & 5 & 2 \\
\hline Słowacja & 933 & 1780 & 17 & 36 & 16 & 21 & 6 & 2 \\
\hline Węgry & 2212 & 2952 & 22 & 33 & 17 & 21 & 4 & 2 \\
\hline Północna Europa & 21971 & 33209 & 22 & 30 & 20 & 29 & 4 & 3 \\
\hline Dania & 1258 & 1626 & 23 & 29 & 18 & 31 & 4 & 3 \\
\hline Estonia & 301 & 393 & 22 & 32 & 18 & 23 & 4 & 2 \\
\hline Finlandia & 1280 & 1736 & 24 & 32 & 19 & 32 & 4 & 2 \\
\hline Irlandia & 717 & 1896 & 16 & 30 & 17 & 24 & 6 & 2 \\
\hline Litwa & 699 & 870 & 21 & 34 & 17 & 25 & 4 & 2 \\
\hline Łotwa & 505 & 643 & 22 & 35 & 17 & 22 & 4 & 2 \\
\hline Szwecja & 2283 & 3192 & 25 & 30 & 22 & 31 & 4 & 2 \\
\hline Wielka Brytania & 13813 & 20869 & 22 & 29 & 21 & 30 & 4 & 3 \\
\hline Europa Poludniowa & 36012 & 57545 & 24 & 37 & 20 & 31 & 4 & 2 \\
\hline Cypr $^{\mathrm{d}}$ & 157 & 354 & 18 & 30 & 16 & 25 & 5 & 3 \\
\hline Grecja & 2678 & 4113 & 24 & 38 & 15 & 28 & 4 & 2 \\
\hline Hiszpania & 9982 & 19235 & 22 & 38 & 22 & 30 & 4 & 2 \\
\hline Malta & 87 & 152 & 21 & 37 & 16 & 26 & 5 & 2 \\
\hline Portugalia & 2497 & 3848 & 23 & 38 & 19 & 29 & 4 & 2 \\
\hline
\end{tabular}




\begin{tabular}{||l|r|r|c|c|c|c|c|c||}
\hline \multicolumn{1}{|c|}{1} & \multicolumn{1}{|c|}{2} & \multicolumn{1}{c|}{3} & 4 & 5 & 6 & 7 & 8 & 9 \\
\hline Słowenia & 442 & 724 & 22 & 37 & 18 & 28 & 4 & 2 \\
\hline Włochy & 15788 & 22310 & 26 & 39 & 22 & 34 & 3 & 2 \\
\hline Europa Zachodnia & $\mathbf{4 5 0 3 3}$ & $\mathbf{6 5 0 4 8}$ & $\mathbf{2 4}$ & $\mathbf{3 5}$ & $\mathbf{2 1}$ & $\mathbf{3 5}$ & $\mathbf{4}$ & $\mathbf{2}$ \\
\hline Austria & 1912 & 3049 & 23 & 36 & 21 & 34 & 4 & 2 \\
\hline Belgia & 2454 & 3717 & 23 & 32 & 21 & 33 & 4 & 2 \\
\hline Francja & 14140 & 22034 & 23 & 33 & 24 & 35 & 4 & 2 \\
\hline Holandia & 3548 & 5445 & 21 & 31 & 18 & 33 & 4 & 2 \\
\hline Luksemburg & 92 & 196 & 19 & 27 & 19 & 28 & 5 & 3 \\
\hline Niemcy & 21134 & 27837 & 26 & 40 & 19 & 36 & 3 & 2 \\
\hline
\end{tabular}

${ }^{a}$ Regiony bardziej rozwinięte - zaliczono do nich wszystkie regiony Europy, Ameryki Północnej, Australię, Nową zelandię i Japonię.

${ }^{\mathrm{b}}$ Regiony mniej rozwinięte - obejmują wszystkie regiony Afryki, Azji (wyłączając Japonię), Ameryki Łacińskiej i Karaibów oraz Melanezji, Polinezji i Mikronezji.

${ }^{\mathrm{c}}$ Regiony najmniej rozwinięte - Zgromadzenie Ogólne ONZ zaliczyło do nich w 2009 r. 49 państw, z których 33 znajdują się w Afryce, 10 w Azji, 1 w Ameryce Łacińskiej i 5 na obszarze Oceanii; stanowią one podzbiór państw rozwijających się.

${ }^{\mathrm{d}}$ Cypr został przez ONZ zaliczony do państw Azji Zachodniej.

Źródło: Population ageing and development 2009, United Nations, New York 2010.

W 2009 r. na świecie żyło ok. 737 mln osób powyżej 60 roku życia, z czego najwięcej, bo ponad połowa zamieszkiwała Azję (54\%), zaś 1/5 Europę (21\%). Do 2050 r. liczba osób starszych ma wzrosnąć do ponad 2 mld. Niezwykle niepokojące są prognozy, wedle których populacja osób powyżej 60 lat będzie wówczas przewyższać liczbę dzieci w wieku 0-14 lat. Obecnie jedna na dziewięć osób przekroczyła 60 lat, w 2050 roku, według prognoz ONZ, wiek ten ma osiagnąć co piąta osoba.

Choć sytuacja ludnościowa na świecie ulega poważnym zmianom, to jednak odsetek osób starszych jest w dalszym ciągu wyższy w krajach rozwiniętych, gdzie proces starzenia się społeczeństw jest znacznie bardziej zaawansowany. Najgorzej wypada Europa, w której jedna na pięć osób przekroczyła już 60 rok życia. Z uwagi na postęp w nauce medycznej wzrasta także liczna osób przekraczających 80 lat. W 2009 r. grupa ta stanowiła 14\% populacji osób powyżej 60 lat, zaś w 2050 r. ich odsetek ma osiągnąć 20\%. Jeszcze szybciej zmienia się liczba „stulatków”, która w ciągu czterech dekad ma się zwiększyć dziewięciokrotnie (z ok. 454 tys. w 2009 r. do 4,1 mln w roku 2050). Drastyczne zmiany w porównaniu z rokiem 1950 nastąpiły także w średniej długości życia. W ciągu kilku dziesięcioleci wzrosła ona o 20 lat i obecnie wynosi $68^{8}$.

Z punktu widzenia wypłacalności systemów emerytalnych oraz problemu ubóstwa osób starszych niezwykle istotne są zmiany w obszarze wskaźnika określanego jako wsparcie osób starszych. Stanowi on stosunek liczby osób z przedziału 15-64 lat do osób powyżej 65 roku życia. Jest to zarazem z jednej strony współczynnik poziomu starzenia się społeczeństwa, z drugiej natomiast wskazuje na stopień zależności osób starszych od potencjalnych pracowników. W 1950 r. na świecie na jedną osobę powyżej 65 r. ż. przypadało 12 osób między 15 a 64 r.ż. W 2009 r. liczba ta spadła do 9 i w kolejnych latach ma dalej się obniżać, by w 2050 r. sięgnąc poziomu czterech osób ${ }^{9}$.

\footnotetext{
${ }^{8}$ Population ageing and development 2009, United Nations, New York 2010.

${ }^{9}$ Population ageing and development 2009, United Nations, New York 2010.
} 
Spośród państw europejskich najwyższy odsetek osób powyżej 60 r.ż. mieszczący się w przedziale 23-26\%, obserwuje się w wysoko rozwiniętych krajach północno- i zachodnioeuropejskich, takich jak Dania, Finlandia, Szwecja, Grecja, Portugalia, Włochy, Austria, Belgia, Francja i Niemcy. Na ich tle Polska wypada bardzo dobrze i zalicza się do państw o jednym z najniższych odsetków osób przekraczających 60 lat. Niemniej jednak w ciągu następnych 40 lat, prognozuje się, że wskaźnik ten ulegnie drastycznemu wzrostowi z 19 do $38 \%$, osiagając tym samym jeden z najwyższych poziomów tego wskaźnika w Europie. Tak poważny wzrost liczby osób w wieku poprodukcyjnym stanowi wyzwanie dla nowoczesnych gospodarek, a w szczególności dla polityki społecznej tak Unii Europejskiej, jak i poszczególnych jej członków. Zauważa się, iż problem ubóstwa w państwach rozwiniętych skorelowany jest $\mathrm{z}$ wiekiem i dotyczy przede wszystkim dzieci oraz właśnie osób starszych ${ }^{10}$.

\section{Skala zjawiska w Europie}

Mimo wysokiego poziomu życia w krajach UE część osób w dalszym ciagu pozostaje na „marginesie”. Jednym z mierników stosowanych na poziomie unijnym jest wskaźnik zagrożenia ubóstwem i wykluczeniem społecznym.

Tabela 2

Ludność zagrożona ubóstwem i wykluczeniem społecznym (\% z populacji)

\begin{tabular}{|c|c|c|c|c|c|c|c|}
\hline \multirow{2}{*}{ Państwo } & \multicolumn{7}{|c|}{ Rok } \\
\hline & 2005 & 2006 & 2007 & 2008 & 2009 & 2010 & 2011 \\
\hline 1 & 2 & 3 & 4 & 5 & 6 & 7 & 8 \\
\hline UE 27 & $25,6^{\mathrm{s}}$ & $25,2^{\mathrm{s}}$ & 24,4 & 23,5 & 23,1 & 23,4 & - \\
\hline Austria & 17,5 & 16,8 & 17,8 & 16,7 & 18,6 & 17,0 & 16,6 \\
\hline Belgia & 21,6 & 22,6 & 21,5 & 21,6 & 20,8 & 20,2 & 20,8 \\
\hline Bułgaria & - & - & 61,3 & 60,7 & $38,2^{\mathbf{b}}$ & 46,2 & 41,6 \\
\hline Cypr & - & 25,3 & 25,4 & 25,2 & $22,4^{b}$ & 22,9 & 23,6 \\
\hline Czechy & - & 19,6 & 18,0 & 15,8 & 15,3 & 14,0 & 14,4 \\
\hline Dania & 16,5 & 17,2 & 16,7 & 16,8 & 16,3 & 17,6 & 18,3 \\
\hline Estonia & 26,3 & 25,9 & 22,0 & 22,0 & 21,8 & 23,4 & 21,7 \\
\hline Finlandia & 17,2 & 17,2 & 17,1 & 17,4 & 17,4 & 16,9 & 16,9 \\
\hline Francja & 19,8 & 18,9 & 18,8 & 19,0 & $18,6^{\mathbf{b}}$ & 18,5 & 19,2 \\
\hline Grecja & 30,9 & 29,4 & 29,3 & 28,3 & 28,1 & 27,6 & 27,7 \\
\hline Hiszpania & 24,4 & 23,4 & 23,3 & 23,1 & 22,9 & 23,4 & 25,5 \\
\hline Holandia & - & 16,7 & 16,0 & 15,7 & 14,9 & 15,1 & 15,1 \\
\hline Irlandia & 24,8 & 25,0 & 23,3 & 23,1 & 23,7 & 25,7 & 29,9 \\
\hline Litwa & - & 41,0 & 35,9 & 28,7 & 27,6 & 29,5 & 33,4 \\
\hline Luksemburg & 16,1 & 17,3 & 16,5 & 15,9 & 15,5 & 17,8 & 17,1 \\
\hline Łotwa & - & 45,8 & 41,4 & 36,0 & $33,8^{\mathbf{b}}$ & 37,4 & 38,1 \\
\hline Malta & - & 20,2 & 19,1 & 19,4 & 19,6 & 20,2 & 20,3 \\
\hline Niemcy & - & 18,4 & 20,2 & 20,6 & 20,1 & 20,0 & 19,7 \\
\hline
\end{tabular}

${ }^{10}$ Population ageing and development 2009, United Nations, New York 2010. 


\begin{tabular}{|l|c|c|c|c|c|c|c||}
\hline \multicolumn{1}{|c|}{1} & 2 & 3 & 4 & 5 & 6 & 7 & 8 \\
\hline Polska & - & 45,3 & 39,5 & 34,4 & $30,5^{\mathbf{b}}$ & 27,8 & 27,8 \\
\hline Portugalia & 27,5 & 26,1 & 25,0 & 25,0 & 26,0 & 24,9 & 25,3 \\
\hline Rumunia & - & - & - & 45,9 & 44,2 & 43,1 & 41,4 \\
\hline Słowacja & - & 32,0 & 26,7 & 21,3 & 20,6 & 19,6 & 20,6 \\
\hline Słowenia & - & 18,5 & 17,1 & 17,1 & 18,5 & 17,1 & 18,3 \\
\hline Szwecja & 16,9 & 14,4 & 16,3 & 13,9 & 14,9 & 15,9 & 15,0 \\
\hline Węgry & - & 32,1 & 31,4 & 29,4 & 28,2 & 29,6 & 29,9 \\
\hline Wielka Brytania & - & 24,8 & 23,7 & 22,6 & 23,2 & 22,0 & 23,1 \\
\hline Włochy & 26,4 & 25,0 & 25,9 & 26,0 & 25,3 & 24,7 & 24,5 \\
\hline \hline
\end{tabular}

$-=$ brak danych;

$\mathrm{s}=$ szacunki Eurostatu;

$\mathrm{b}=$ przerwa $\mathrm{w}$ serii danych;

$\mathrm{p}=$ dane tymczasowe.

Źródło: http://epp.eurostat.ec.europa.eu/portal/page/portal/income_social_inclusion_living_conditions/data/main_tables, z dnia 7.11.2012.

Jak wynika z tabeli 2 w latach 2005-2011 generalnie wartości wskaźnika zagrożenia ubóstwem i wykluczeniem społecznym wykazują tendencję spadkową. Niemniej jednak w kilku państwach po początkowym spadku, w latach 2010 i 2011 wskaźnik ten zaczął rosnąc. Największy przyrost w stosunku do roku 2009 zanotowano w Irlandii $(6,2 \%)$, na Litwie $(5,8 \%)$ i Łotwie (4,3\%). Ok. 2-procentowy wzrost odnotowano w Danii (2\%), na Wegrzech $(1,7 \%)$ i w Luksemburgu (1,6\%). Pomimo wyraźnej poprawy, czyli spadku wskaźnika, w kilku państwach jego wartość nadal pozostaje na bardzo wysokim poziomie. W Bułgarii w $2011 \mathrm{r}$. sięgnał pułapu 41,6\% i nieznacznie mniej, bo 41,4\% w Rumunii. Wysoki jego poziom odnotowano ponadto na Łotwie $(38,1 \%)$, Węgrzech $(29,9 \%)$ i w Irlandii $(29,9 \%)$. Warto w tym miejscu zaznaczyć, iż są to zarazem państwa, w których wskaźnik ten w ostatnich latach wzrósł. Najniższy jego poziom zanotowano natomiast $\mathrm{w}$ państwach skandynawskich, tj. w Szwecji (15,0\%), Holandii (15,1\%), Finlandii (16,9\%), a także w Czechach (14,4\%) i Austrii $(16,6 \%)$.

Tabela 3

Zagrożeni ubóstwem i wykluczeniem społecznym w 2010 r. (\% z populacji)

\begin{tabular}{|c|c|c|c|c|c|}
\hline \multirow[t]{2}{*}{ Państwo } & \multirow[t]{2}{*}{$\begin{array}{l}\text { Ludność } \\
\text { zagrożona } \\
\text { ubóstwem po } \\
\text { transferach } \\
\text { socjalnych }\end{array}$} & \multirow[t]{2}{*}{$\begin{array}{c}\text { Ludność żyjąca } \\
\text { w warunkach } \\
\text { poważnej } \\
\text { deprywacji } \\
\text { materialnej }\end{array}$} & \multirow[t]{2}{*}{$\begin{array}{l}\text { Ludność w wieku } \\
\text { 0-59 lat żyjąca } \\
\text { w gospodarstwie } \\
\text { domowym bar- } \\
\text { dzo małej inten- } \\
\text { sywności pracy }\end{array}$} & \multicolumn{2}{|c|}{$\begin{array}{l}\text { Ludność spełniająca warunki } \\
\text { klasyfikacji do co najmniej } \\
\text { jednego z trzech kryteriów } \\
\text { (zagrożenia ubóstwem lub } \\
\text { wykluczenia społecznego) }\end{array}$} \\
\hline & & & & tys. & $\%$ \\
\hline 1 & 2 & 3 & 4 & 5 & 6 \\
\hline UE $27^{\text {s }}$ & 16,4 & 8,1 & 9,9 & 115479 & 23,4 \\
\hline Austria & 12,1 & 4,3 & 7,7 & 1373 & 16,6 \\
\hline Belgia & 14,6 & 5,9 & 12,6 & 2235 & 20,8 \\
\hline Bułgaria & 20,7 & 35,0 & 7,9 & 3145 & 41,6 \\
\hline Czechy & 9,0 & 6,2 & 6,4 & 1495 & 14,4 \\
\hline Cypr & - & - & - & - & - \\
\hline
\end{tabular}




\begin{tabular}{|c|c|c|c|c|c|}
\hline 1 & 2 & 3 & 4 & 5 & 6 \\
\hline Dania & 13,3 & 2,7 & 10,3 & 1007 & 18,3 \\
\hline Estonia & 15,8 & 9,0 & 8,9 & 289 & 21,7 \\
\hline Finlandia & 13,1 & 2,8 & 9,1 & 890 & 16,9 \\
\hline Francja & 13,5 & 5,8 & 9,8 & 11763 & 19,3 \\
\hline Grecja & 20,1 & 11,6 & 7,5 & 3031 & 27,7 \\
\hline Hiszpania & 20,7 & 4,0 & 9,8 & 11675 & 25,5 \\
\hline Holandia & 10,3 & 2,2 & 8,2 & 2483 & 15,1 \\
\hline Irlandia & - & - & - & - & - \\
\hline Litwa & 20,2 & 19,5 & 9,2 & 1109 & 33,4 \\
\hline Luksemburg & 14,5 & 0,5 & 5,5 & 83 & 17,1 \\
\hline Łotwa & 21,3 & 27,4 & 12,2 & 846 & 38,1 \\
\hline Malta & 15,5 & 5,7 & 8,4 & 84 & 20,6 \\
\hline Niemcy & 15,6 & 4,5 & 11,1 & 15962 & 19,7 \\
\hline Polska & 17,6 & 14,2 & 7,3 & 10409 & 27,8 \\
\hline Portugalia & 17,9 & 9,0 & 8,6 & 2693 & 25,3 \\
\hline Rumunia & 21,1 & 31,0 & 6,8 & 8890 & 41,4 \\
\hline Słowacja & 12,0 & 11,4 & 7,9 & 1118 & 20,6 \\
\hline Słowenia & 12,7 & 5,9 & 6,9 & 366 & 18,3 \\
\hline Szwecja & 12,9 & 1,3 & 5,9 & 1418 & 15,0 \\
\hline Węgry & 12,3 & 21,6 & 11,8 & 2948 & 29,9 \\
\hline Wielka Brytania & 17,1 & 4,8 & 13,1 & 14209 & 23,1 \\
\hline Włochy & 18,2 & 6,9 & 10,2 & 14742 & 24,5 \\
\hline
\end{tabular}

$-=$ brak danych,

$\mathrm{s}=$ szacunki.

Źródło: Eurostat news release, 21/2012 - 8 February 2012.

Analizując zaprezentowane w tabeli 3 dane, można zauważyć, iż najwyższy poziom pierwszego ze subwskaźników, zanotowały państwa borykające się w ostatnich latach z poważnymi problemami finansowymi, tj. Hiszpania (20,7\%), Grecja (20,1\%) i Włochy $(18,2 \%)$, najmłodsze stażem państwa unijne, czyli Rumunia $(21,1 \%)$ i Bułgaria $(20,7 \%)$ oraz Łotwa (21,3\%) i Litwa (20,2\%). Bułgaria, Rumunia i Łotwa są zarazem państwami, w których wysoki poziom osiaga także skala poważnej deprywacji materialnej. Natomiast w obszarze wskaźnika, bardzo małej intensywności pracy, najwyższe wartości zanotowano w Wielkiej Brytanii $(13,1 \%)$, Belgii $(12,6 \%)$ oraz Niemczech $(11,1 \%)$, co może się wiązać z wysokością wsparcia, jakie otrzymują w tych państwach bezrobotni, a także na Łotwie (12,2\%) i Węgrzech $(11,8 \%)$. Co najmniej jedna $\mathrm{z}$ trzech form ubóstwa lub wykluczenia społecznego dotyczy 41,6\% Bułgarów, 44,4\% Rumunów 38,1\% Łotyszy i 33,4\% Litwinów.

\section{Komisja Europejska wobec ubóstwa}

O skali i wadze ubóstwa świadczy fakt, iż walka z ubóstwem została przez Komisję Europejską uznana za jeden z pięciu, obok kwestii zatrudnienia, badań i innowacji, zmian klimatu i energii oraz edukacji, podstawowych kierunków wytyczonych w dokumencie strategicznym 
Europa $2020^{11}$. W obszarze każdego z nich wyznaczono także wymierne cele, do których mają doprowadzić podejmowane tak na poziomie wspólnotowym, jak i krajowym działania. Wpisują się one także w realizację trzech ogólnych, powiązanych ze sobą priorytetów, do których zaliczono:

— rozwój inteligentny - dotyczy rozwoju gospodarki opartej na wiedzy i innowacyjności;

— rozwój zrównoważony - koncentruje się wokół wspierania gospodarki efektywniej korzystającej z zasobów, bardziej konkurencyjnej i przyjaznej środowisku;

- rozwój sprzyjający łączeniu społecznemu - dotyczy wspierania gospodarki charakteryzującej się wysokim zatrudnieniem, zapewniającej spójność społeczną i terytorialną ${ }^{12}$.

W odniesieniu do kwestii ubóstwa uznano, iż do roku 2020 liczbę osób nim zagrożonych należy zmniejszyć o $25 \%$, tj. 20 mln. W dokumencie zauważono, iż przed kryzysem gospodarczym ubóstwem zagrożonych było $80 \mathrm{mln}$ osób, z czego $19 \mathrm{mln}$ stanowiły dzieci. Niepokojącym są również dane, wedle których $8 \%$ osób nie zarabia wystarczająco, aby przekroczyć próg ubóstwa. Stąd też wynika, iż nie tylko bezrobotni są zagrożeni ubóstwem, ale także pracujący, gdyż zatrudnienie nie jest gwarantem osiągania środków niezbędnych do zaspokojenia podstawowych potrzeb materialnych ${ }^{13}$.

Dla osiagnięcia poszczególnych celów Komisja przedstawiła ponadto siedem przewodnich inicjatyw, z których każda skoncentrowana jest wokół innego obszaru. Jedna z nich to „Europejski program walki z ubóstwem”"14, który stanowi kontynuację idei Europejskiego Roku Walki z Ubóstwem i Wykluczeniem Społecznym obchodzonego w 2010 r. Przedstawione w strategii ramy programu obejmują działania podejmowane zarówno na poziomie wspólnotowym, jak i krajów członkowskich. Komisja Europejska zamierza:

- przeformułować otwartą metodę koordynacji w zakresie wyłączenia społecznego i ochrony socjalnej w zorganizowaną platformę wzajemnych kontaktów i współpracy oraz instrument zachęcający do podejmowania działań w walce z wykluczeniem społecznym, w szczególności z wykorzystaniem funduszy strukturalnych, w tym EFS;

— opracować i wdrożyć programy promujące innowacje społeczne na rzecz osób w trudnej sytuacji społeczno-ekonomicznej, podejmować działania mające na celu walkę z dyskryminacją, opracować nowy program integracji imigrantów;

— ocenić adekwatność i trwałość systemów ochrony socjalnej i emerytalnych oraz wykreować sposoby lepszej dostępności do systemów opieki zdrowotnej ${ }^{15}$.

Program nakłada także pewne powinności wobec państw członkowskich, które będą zobowiązane do:

— promowania poczucia odpowiedzialności za walkę z ubóstwem i wykluczeniem społecznym;

— opracowania i wdrożenia programów działań mających na celu rozwiązanie konkretnych problemów szczególnie zagrożonych grup społecznych;

\footnotetext{
${ }^{11}$ Komunikat Komisji Europejskiej, Europa 2020. Strategia na rzecz inteligentnego i zrównoważonego rozwoju sprzyjajacego właczeniu społecznemu, KOM(2010) 2020, Bruksela, 3.03.2010 wersja ostateczna.

${ }_{12}$ Komunikat Komisji Europejskiej, Europa 2020. Strategia na rzecz inteligentnego i zrównoważonego rozwoju sprzyjajacego właczeniu społecznemu, KOM(2010) 2020, Bruksela, 3.03.2010 wersja ostateczna, s. 5, 21.

${ }_{13}$ Dla wyznaczenia tej liczby założono, iż ubóstwo dotyczy osób, które żyją poniżej krajowej granicy ubóstwa, za którą przyjęto próg 60\% krajowej mediany rozporządzalnego dochodu w każdym państwie członkowskim.

${ }^{14}$ Pełna nazwa tej inicjatywy zaprezentowana w polskiej wersji komunikatu Komisji z dnia 16.12.2010 brzmi: Europejska platforma współpracy w zakresie walki z ubóstwem i wykluczeniem społecznym.

${ }^{15}$ Komunikat Komisji Europejskiej, Europa 2020. Strategia na rzecz inteligentnego i zrównoważonego rozwoju sprzyjajacego właczeniu społecznemu, $\operatorname{KOM(2010)~2020,~Bruksela,~3.03.2010~wersja~ostateczna,~s.~} 22$.
} 
— pełnego wykorzystywania swoich systemów ochrony socjalnej i emerytalnych celem wsparcia dochodów oraz zapewnienia dostępu do opieki zdrowotnej ${ }^{16}$.

Szczegółowe założenia inicjatywy zostały zawarte w komunikacie Komisji z dnia 16 grudnia 2010 r. $^{17}$

\section{Zakończenie}

Ubóstwo jest zjawiskiem powszechnym i choć w szczególności dotyczy państw rozwijających się, to jednak jest ono widoczne także w tzw. państwach rozwiniętych. Mimo wysokiego poziomu życia w krajach Unii Europejskiej, cześć osób w dalszym ciagu pozostaje na „marginesie społeczeństwa”. W grupie podwyższonego ryzyka znajdują się dzieci, a także osoby starsze, których w Europie przybywa. Komisja Europejska podejmuje działania formalne np. ustanawiając rok 2010 Europejskim Rokiem Walki z Ubóstwem i Wykluczeniem Społecznym. Mimo tych działań ciągle część społeczeństwa w krajach unijnych nie korzysta z uzyskanego w tych krajach poziomu życia w obszarze ekonomicznym i socjalnym.

\section{The Issue of Poverty in the European Union}

\section{Summary}

The issues of poverty, famine and malnutrition mainly concern underdeveloped regions. Yet in recent years the proportion of the population threatened with poverty and social exclusion has been growing not only in these regions but also in developed areas, including the EU. The issue of poverty is additionally related to demography. In this context, the aging population of West European countries is worrisome, as the elderly are one of the groups particularly threatened by poverty, and their number continues to grow. Appreciating the gravity of this issue, the European Commission considers the fight against poverty to be one of the basic five directions established in the Europe 2020 strategic document.

\footnotetext{
${ }^{16}$ Komunikat Komisji Europejskiej, Europa 2020. Strategia na rzecz inteligentnego i zrównoważonego rozwoju sprzyjajacego właczeniu społecznemu, KOM(2010) 2020, Bruksela, 3.03.2010 wersja ostateczna, s. 22.

${ }^{17}$ Komunikat Komisji do Parlamentu Europejskiego, Rady, Europejskiego Komitetu Ekonomiczno-Społecznego oraz Komitetu Regionów, Europejska platforma wspólpracy w zakresie walki z ubóstwem i wykluczeniem społecznym: europejskie ramy na rzecz spójności społecznej i terytorialnej, Bruksela, dnia 16.12.2010, KOM(2010) 758 wersja ostateczna.
} 